\title{
(息)
}

Citation:

Woodall, J and Dixey, R (2015) Advancing the health-promoting prison: a call for global action. Global health promotion. ISSN 1757-9759 DOI: https://doi.org/10.1177/1757975915581760

Link to Leeds Beckett Repository record:

https://eprints.leedsbeckett.ac.uk/id/eprint/1020/

Document Version:

Article (Accepted Version)

The aim of the Leeds Beckett Repository is to provide open access to our research, as required by funder policies and permitted by publishers and copyright law.

The Leeds Beckett repository holds a wide range of publications, each of which has been checked for copyright and the relevant embargo period has been applied by the Research Services team.

We operate on a standard take-down policy. If you are the author or publisher of an output and you would like it removed from the repository, please contact us and we will investigate on a case-by-case basis.

Each thesis in the repository has been cleared where necessary by the author for third party copyright. If you would like a thesis to be removed from the repository or believe there is an issue with copyright, please contact us on openaccess@leedsbeckett.ac.uk and we will investigate on a case-by-case basis. 


\section{Advancing the health promoting prison: a call for global action}

The global prison population has grown exponentially in all five continents, to a reported 10 million (1). Imprisonment is a common form of punishment, as in almost all jurisdictions the prison occupies a prominent place in the politics of crime control and symbolises the apex of the criminal justice system (2) (albeit in some countries the death penalty still exists).

Epidemiological assessment demonstrates that many diseases, illnesses and long-term conditions are over-represented in the prison population showing that this group faces a myriad of health challenges (3). Whether these health issues are caused by imprisonment or are 'imported' into prison as a result of individuals' prior circumstances is debateable, although it is acknowledged both are implicated (4). The health gap between prisoners and the general community has led some to argue that health promotion in the prison population is as much, if not more, significant than efforts in the community (5). Nonetheless, the concept and practice of health promotion is both contested and underdeveloped with significant variation in its application in prison systems globally (4). The purpose of this commentary paper is twofold. The first is to provide a short overview of the health promoting prison concept which we argue, at present, is a largely Eurocentric idea which has not been adopted on a global scale. Second, the paper makes a case for more global action on prison health promotion and invites further dialogue and discussion amongst the health promotion community.

Scholars and practitioners in the field of health promotion will be aware of the premise of settings-based approaches. Originating from the Ottawa Charter and drawing on an 
ecological perspective of health (6), the settings-based movement has been particularly prominent and successful in a number of locales, notably schools and workplaces (7). Although originally criticised as a re-badging of other forms of health promotion intervention (8), the approach has now become a mainstay of health promotion activity with the theory and conceptual understanding of settings-based approaches evolving continuously (9). The concept of a health promoting prison is guided by several key principles, none more so than prisoners' rights which are at the core of the initiative. Indeed, in 1966 the United Nations in their International Covenant on Economic, Social and Cultural Rights (10) stated that every citizen has the right to the highest attainable standard of physical and mental health and, in 1990, they declared that prisoners should have access to health services available in the country without discrimination based on their legal status (11). Linked to prisoners' rights is the principle of healthcare equivalence. The premise is that individuals detained in prison must have the benefit of care equivalent of that available to the general public (12).

The health promoting prison, however, is not simply about equivalent health care, but also represents an opportunity to promote the health of a literally 'captive population'. Consistent with the principles of the settings-approach, it should include a focus on all facets of the organisation, not merely attempts to address individual health need through health education. The Ottawa Charter (13) is a useful framework to envisage these facets of prison life and has been used to map settings-based interventions in prisons (14). The Charter principles have further been observed in very recent WHO guidance which advocates for healthy prison policy and for a supportive environment that enables health to be fostered (15). 
While there are health promoting settings that are being operationalized at a global level (e.g. healthy cities), health-promoting prisons are not at this stage. That aside, the work developed in Europe has been particularly prominent (16) and is seen as a model for expansion globally (17). Nonetheless, the health-promoting prison philosophy is less-well developed in resource-poor regions. In sub-Saharan Africa for example, prisons were recently summarised as being often inhumane, not spacious enough and not providing adequate food or health care $(18,19)$.

Prisons across Africa represent severe threats to health: "The appalling physical conditions of African prisons, along with inadequate food and nutrition and almost non-existent health services, seriously exacerbate the prevalence of HIV inside prisons" (20, p.17). Even in South Africa, there is little knowledge or research about the state of prison health services (21). Prisons in Zambia have been described as 'death traps' where prisoners are 'imperilled' (22) and subjected to the 'double sentence' of imprisonment and acquiring HIV (23). This is not to say that Zambian prisons should be singled out - no doubt poor conditions are to be found throughout Africa, but Zambia has quite an open (and commendable) policy of access to their prisons. Given the poverty facing many sub-Saharan African countries, there are clearly resourcing and structural differences between European and African health systems and health promotion efforts (24). Moreover, health promotion remains Eurocentric in its origins and value base and it has been argued that theoretical agency needs to be grounded in other world-views (25), especially where those world-views are based on a less individualist and more communitarian perspective, such as throughout Asia and Africa. 
There are also ideological differences between continents and differences about who is and who is not deserving of support. Some of these differences are displayed in incarceration rates and in the punitive or rehabilitative nature of the criminal justice system. The USA has a notoriously high imprisonment rate of 716 per 100,000; in contrast Iceland has 47 (1). These differences show not merely different crime rates, but different approaches to social problems, to the causes of crime and how society should deal with offenders.

Interestingly, it has been in those countries dominated by social-liberal democracies that have taken a lead in more humanitarian approaches to offending behaviour. In the mid1990s European WHO officials launched a drive to see prisoners being more empowered and enabled to take control over their health (25). There was heavy criticism of the health promoting prison concept when the idea was first proposed with the idea largely regarded as an oxymoron (26). From historical analysis of policy and strategy formulation (27), we would argue that the health promoting prison concept is no longer regarded in this way in discrete parts of the world and is seen by some Euro-WHO members states as a viable framework to address the health inequalities faced by the prison population. This viewpoint, however, is not universally held across all nations.

The discipline of health promotion and its associated values-base of empowerment, control and choice, partnership-working, and equity, has a great deal to contribute to prison health and, in our view, should be an integral part of good prison management. The health promoting prison is, by comparison to other settings, still in its infancy, with a number of institutional barriers to implementation (28). Nonetheless, the opportunity to impact positively on the health of the 10 million people that make up the global prison population 
should not be overlooked and we look forward to the global health promotion community coming together to debate and consider these matters. One action would be to draw together all those initiatives that are working to make prisons more humane and healthpromoting places, examples of which do exist (29). That said, the challenges in creating health promoting prisons should not be understated and while there are transferable learning to prison from other health promoting settings, such as schools, the unique nature of this context does create distinct issues. Take, as an example, the power dynamics that exist between prisoners and staff and the difficulties in ensuring that all members of the setting have an opportunity to share their views equally. To some extent, prisons are inherently hierarchical and disempowering places which are clearly antithetical to health promotion values (30). The authors welcome further discussion on addressing the inequalities faced by the prison population and hope that the issues raised will be a catalyst for the health promotion community to develop understanding of, and take action on, not only prison conditions but also the determinants of prisoner health.

\section{References}

1. Walmsley R. World prison population list (10th edn). London: International Centre for Prison Studies, 2013.

2. Sparks R. The politics of imprisonment. In: Jewkes Y, editor. Handbook on prisons. Cullompton: Willan Publishing; 2007. p. 73-94.

3. WHO. Health in prisons. A WHO guide to the essentials in prison health. Copenhagen: WHO, 2007. 
4. Woodall J, de Viggiani N, Dixey R, South J. Moving prison health promotion along: toward an integrative framework for action to develop health promotion and tackle the social determinants of health. Criminal Justice Studies. 2014;27(1):114-32.

5. Ross M. Health and health promotion in prisons. Oxon: Routledge; 2013.

6. Green J, Tones K, Cross R, Woodall J. Health promotion. Planning and strategies. 3rd Edn ed. London: Sage; 2015.

7. Scriven A, Hodgins M. Health promotion settings: principles and practice. London: Sage; 2012.

8. Wenzel E. A comment on settings in health promotion. Internet Journal of Health Promotion. 1997; http://www.rhpeo.org/ijhp-articles/1997/1/index.htm.

9. Dooris M. Expert voices for change: Bridging the silos-towards healthy and sustainable settings for the 21st century. Health \& Place. 2013;20:39-50.

10. United Nations. International covenant on economic, social and cultural rights Geneva: Office of the United Nations High Commissioner for Human Rights 1966.

11. United Nations. Basic principles for the treatment of prisoners. Adopted and proclaimed by General Assembly resolution 45/111 of 14 December 1990. New York: United Nations, 1990.

12. Niveau G. Relevance and limits of the principle of "equivalence of care" in prison medicine. Journal of Medical Ethics. 2007;33(10):610-3.

13. WHO. Ottawa Charter for health promotion. Health Promotion. 1986;1(4):iii - v. 
14. Ramaswamy M, Freudenberg N. Health promotion in jails and prisons: an alternative paradigm for correctional health services. In: Greifinger RB, Bick J, Goldenson J, editors. Public health behind bars From prisons to communities. New York: Springer; 2007. p. 22948.

15. Baybutt $M$, Acin $E$, Hayton $P$, Dooris $M$. Promoting health in prisons: a settings approach. In: Enggist S, Møller L, Galea G, Udesen C, editors. Prisons and health. Copenhagen: WHO; 2014. p. 180-4.

16. Møller L, Gatherer A, Dara M. Barriers to implementation of effective tuberculosis control in prisons. Public Health. 2009;123(6):419-21.

17. Anon. Advocates working to improve prison health in the Americas. The Nation's Health. 2008;38(1):4.

18. Tertsakian C. 'Some prisons are prisons, and others are like hell.' Prison life in Rwanda in the ten years after the genocide. Prison Service Journal. 2014;212:4-10.

19. Jefferson AM, Martin TM. Everyday prison governance in Africa. Prison Service Journal. 2014;212:2-3.

20. UNODC, UNAIDS. HIV and prisons in Sub-Saharan Africa: opportunities for action. New York: UNODC and UNAIDS, 2006.

21. Sifunda S, Reddy PS, Braithwaite R, Stephens T, Ruiter RAC, van den Borne B. Access point analysis on the state of health care services in South African prisons: a qualitative 
exploration of correctional health care workers' and inmates' perspectives in Kwazulu-Natal and Mpumalanga. Social Science \& Medicine. 2006;63(9):2301-9.

22. Todrys KW, Amon JJ, Malembeka G, Clayton M. Imprisoned and imperiled: access to HIV and TB prevention and treatment, and denial of human rights, in Zambian prisons. Journal of the International AIDS Society. 2011;14(1):8.

23. Simooya O, Sanjobo N. 'In But Free' - an HIV/AIDS intervention in an African prison. Culture, Health \& Sexuality. 2001;3(2):241-51.

24. Dixey R. After Nairobi: can the international community help to develop health promotion in Africa? Health Promotion International. 2014;29(1):185-94.

25. WHO. Health in prisons. Health promotion in the prison setting. Summary report on a WHO meeting, London 15-17 October 1995. Copenhagen: WHO, 1995.

26. de Viggiani N. Surviving prison: exploring prison social life as a determinant of health. International Journal of Prisoner Health. 2006;2(2):71-89.

27. Woodall J. Control and choice in three category-C English prisons: implications for the concept and practice of the health promoting prison. Unpublished PhD thesis. Leeds: Leeds Metropolitan University; 2010.

28. Dixey R, Woodall J. Prison staff and the health promoting prison. International Journal of Prisoner Health. 2011;7(4):8-16.

29. South J, Bagnall A, Hulme C, Woodall J, Longo R, Dixey R, et al. A systematic review of the effectiveness and cost-effectiveness of peer-based interventions to maintain and 
improve offender health in prison settings. Report for the National Institute for Health Research (NIHR) Health Services and Delivery Research (NIHR HS\&DR) programme Project: 10/2002/13. 2014

30. Woodall J, South J. Health promoting prisons: dilemmas and challenges. In: Scriven A, Hodgins $M$, editors. Health promotion settings: principles and practice. London: Sage; 2012. p. $170-86$. 